\title{
Response of Growth of Quality Protein Maize (QPM) as Influenced by Sulphur Levels and Method of Application
}

\author{
N. Navatha ${ }^{1 *}$, K.P. Vani ${ }^{2}$, P. Surendra Babu ${ }^{3}$ and A. Srinivas ${ }^{2}$ \\ ${ }^{1}$ ICAR-ATARI, ZONE-V, Hyderabad, India \\ ${ }^{2}$ Department of Agronomy, College of Agriculture, Rajendranagar, Professor Jayashankar \\ Telangana State Agricultural University, Hyderabad-500030, India \\ ${ }^{3}$ Department of Soil Science and Chemistry, College of Agriculture, Rajendranagar, Professor \\ Jayashankar Telangana State Agricultural University, Hyderabad-500030, India \\ *Corresponding author
}

\section{A B S T R A C T}

\begin{tabular}{|l|}
\hline Ke y w or d s \\
Growth, LAI, Dry \\
matter production, \\
Sulphur levels, \\
Application method, \\
Quality Protein \\
Maize.
\end{tabular}

A field experiment was conducted to study the effect of different levels and two methods of sulphur application on growth parameters of quality protein maize (QPM) at College farm, Professor Jayashankar Telangana State Agricultural University, Hyderabad, during 2014-2015 using factorial randomized block design (FRBD) with three replications and eight combinations as four different sulphur levels $\left(10 \mathrm{~kg} \mathrm{ha}^{-1}, 20 \mathrm{~kg} \mathrm{ha}^{-1}, 30 \mathrm{~kg} \mathrm{ha}^{-1}\right.$ and $\left.40 \mathrm{~kg} \mathrm{ha}^{-1}\right)$ and two methods of sulphur application $\left(\mathrm{M}_{1}: 100 \%\right.$ basal as single dose; $\mathrm{M}_{2}$ : Two split applications: 50\% each at basal and knee heigh stage). Maximum plant height, LAI and Dry matter production was obtained with $40 \mathrm{~kg} \mathrm{~S} \mathrm{ha}^{-1}$ as compared to $30 \mathrm{~kg} \mathrm{Sha}^{-1}$, $20 \mathrm{~kg} \mathrm{~S} \mathrm{ha}^{-1}$ and $10 \mathrm{~kg} \mathrm{~S} \mathrm{ha}^{-1}$. Similarly, two methods of application split application of sulphur at basal and knee heigh stage shown maximum plant height, LAI and Dry matter production. Almost all the treatments have significantly affected in 60 DAS, 90 DAS and harvest stage of plant height, LAI, Dry matter production but 30 DAS is shown no significant. Plant population and days to $50 \%$ flowering has shown no significant effect. Application of sulphur at $40 \mathrm{~kg} \mathrm{ha}^{-1}$ along with split method of application can be recommended for sustaining productivity and profitability in quality protein maize. The right quantity and application at correct stage of the plant is important for growth and development of QPM.

\section{Introduction}

Maize is considered a promising option for diversifying agriculture in areas of India. It now ranks as the third most important food grain crop in India. The maize area has slowly expanded over the past few years and predicted that this area would grow further to meet future food, feed, and other demands, especially in view of the booming livestock and poultry producing sectors in the country.
To minimize prevalence and persistence of malnutrition in developing countries, when modified to produce a vitreous endosperm resembling that of Conventional Maize, maize that contains approximately double the amount of lysine and tryptophan has been named as "quality protein maize" (QPM). QPM is a cheap source of protein, given that farmers can grow, manage, harvest and 
consume it in the same way they do Conventional Maize varieties (Vasal, 1999).

Maize is an exhaustive crop and absorbs huge quantity of nutrient from the soil during different stages of growth. Sulphur is an essential nutrient for animal and all plant life. Generally, plants require about a tenth as much sulphur $(\mathrm{S})$ as nitrogen $(\mathrm{N})$, but sulphur deficiencies restrict plant growth as surely and severely as nitrogen deficiencies. It is well known that sulphur is a vital macro element in plant growth. Sulphur is a macro element in plant growth and increases the absorption of micronutrients by $\mathrm{pH}$ decreasing. Plant takes up approximately the same amount of sulphur as that of phosphorus (Tandon, 1991).

Sulphur importance is increasing in all regions of the world and in some areas is second to nitrogen in importance (Muhammad, 1994). Sulphur deficiencies are occurring with greater frequency in more locations throughout the world. As a result of its importance many agriculturists are now classifying it as fourth major nutrient. Sulphur plays a vital role in the primary metabolism of higher plants and involved in synthesis of secondary metabolic products in certain groups of plants (Lakkineni and Abrol, 1994) which can have an impact on photosynthesis and grain quality. In the soil, sulphur can exist in many organic and inorganic forms, although plants only take up sulphur in the divalent anion form $\left(\mathrm{SO}_{4}{ }^{2-}\right.$ ) (Patil et al., 1998).

Some of the nitrogen is applied before planting and the rest between tillering and jointing. No similar recommendations exist for sulphur. Since sulphate is an anion similar to nitrate, would a split application of sulphur be beneficial over a single broadcast application to maintain a soil sulphur concentration that is adequate to maximize crop growth and yields and increase grain protein content when sulphur levels are deficient recently, so that a research project is proposed to examine an investigation on different sulphur levels and methods of application (basal and split method of application) on growth and growth parameters of quality protein maize crop.

\section{Materials and Methods}

The experiment was laid out at college farm of Professor Jayashankar Telangana State Agricultural University, Rajendranagar, Hyderabad during kharif season 2014-2015 to study performance of growth of Quality Protein Maize (QPM) as influenced by Sulphur levels and Method of application. The soil of the experimental field was sandy loam in texture, neutral in reaction, low in organic carbon, available nitrogen and sulphur, medium in available phosphorous and high in potassium. Experiment was carried out with four sulphur levels $\left(\mathrm{S}_{1}: 10 \mathrm{~kg}\right.$ $\mathrm{ha}^{-1}, \mathrm{~S}_{2}: 20 \mathrm{~kg} \mathrm{ha}^{-1}, \mathrm{~S}_{3}: 30 \mathrm{~kg} \mathrm{ha}^{-1}$ and $\mathrm{S}_{4}: 40$ $\mathrm{kg} \mathrm{ha}^{-1}$ ) as first factor and method of sulphur application $\left(\mathrm{M}_{1}\right.$ : $100 \%$ basal as single dose; $\mathrm{M}_{2}$ : Two split applications: $-50 \%$ each at basal and knee heigh stage) as second factor comprising eight treatment combination, laid out in randomized block design with factorial concept replicated thrice. Quality protein maize hybrid (HQPM-1) was sown in kharif2014 at a spacing of $60 \mathrm{~cm} \times 20 \mathrm{~cm}$. A uniform dose of $80 \mathrm{~kg} \mathrm{P}_{2} \mathrm{O}_{5}$ as diammonium phosphate, potassium at $80 \mathrm{~kg} \mathrm{ha}^{-1}$ as murate of potash was applied to all the treatments. Entire dose of phosphorous and half of potassium were applied at the time of sowing. Nitrogen was applied as per the treatments through urea in three equal splits (at basal, knee-heigh and tasseling stages). Similarly the remaining potassium and nitrogen was top dressed at tasseling stage. Sulphur was applied through gypsum in two methods of applications i.e. $\mathrm{M}_{1^{-}}-100 \%$ basal application at 
time of sowing; $\mathrm{M}_{2-}$ two split applications:$50 \%$ each at basal and knee heigh stage as per the treatments.

\section{Results and Discussion}

\section{Growth parameters}

\section{Plant population}

Results revealed that there was no significant variation in plant stand due to either sulphur levels or method of application. However, on an average $3.2 \%$ of plant population reduction was noticed from initial to final plant population. The results on initial and final plant population of quality protein maize as influenced by sulphur levels and method of application are presented in table 1 .

\section{Plant height}

The results of plant height of quality protein maize at all crop growth stages as influenced by sulphur levels and method of application are presented in table 2. As the crop aged from 30 to $90 \mathrm{DAS}$, the plant height increased progressively with sulphur levels and method of application, but showed declining rate of increase at harvest. At 30 DAS with increase in sulphur application from 10 to $40 \mathrm{~kg} \mathrm{ha}^{-1}$, The plant height linearly increased, and reached to maximum with $40 \mathrm{~kg} \mathrm{ha}^{-1}(51.8$ $\mathrm{cm})$ and minimum with $10 \mathrm{~kg} \mathrm{~S} \mathrm{ha}^{-1}(40.3$ $\mathrm{cm})$. Among the method of application, the plant height was found to be non-significant.

Among the four sulphur levels $40 \mathrm{~kg} \mathrm{~S} \mathrm{ha}{ }^{-1}$ $\left(\mathrm{S}_{4}\right)$ had recorded significantly maximum plant height $(170 \mathrm{~cm})$ at $60 \mathrm{DAS}$, followed by $30 \mathrm{~kg} \mathrm{ha}^{-1}(161.5 \mathrm{~cm})$ and least plant height of $146.8 \mathrm{~cm}$ with $10 \mathrm{~kg} \mathrm{~S}^{-1}\left(\mathrm{~S}_{1}\right)$. Within the two method of application, split application as basal and at knee heigh stage had resulted in taller plants of $159.6 \mathrm{~cm}$ compared to basal application $(155.7 \mathrm{~cm})$ of sulphur and this difference was statistically significant. As the crop advanced to 90 DAS significantly taller plants were noticed with application of $40 \mathrm{~kg}$ $\mathrm{S} \mathrm{ha}^{-1}(189 \mathrm{~cm})$, followed by $30 \mathrm{~kg} \mathrm{ha}^{-1}(178.3$ $\mathrm{cm})$, and minimum plant height of $163.4 \mathrm{~cm}$ was recorded with $10 \mathrm{~kg}$ sulphur application. Split application of sulphur at basal and knee heigh stage $\left(\mathrm{M}_{2}\right)$ had shown significantly more plant height of $177.7 \mathrm{~cm}$ over that of only $\left(\mathrm{M}_{1}\right)$ basal method of application (173.1 $\mathrm{cm})$.

There was only marginal increase of plant height by the time crop reached harvest stage compared to 90 DAS, where $40 \mathrm{~kg} \mathrm{~S} \mathrm{ha}^{-1}$ had shown plant height of $194.4 \mathrm{~cm}$, followed by $30 \mathrm{~kg} \mathrm{ha}^{-1}(182.5 \mathrm{~cm})$. Least plant height of $166.4 \mathrm{~cm}$ was noticed due to application of 10 $\mathrm{kg} \mathrm{S} \mathrm{ha}{ }^{-1}$. Likewise, split application of sulphur both as basal and at knee heigh stage of the crop $\left(\mathrm{M}_{2}\right)$ produced taller plants at harvest stage $(181.6 \mathrm{~cm})$ compared to that of total amount of sulphur as basal application $\left(\mathrm{M}_{1}\right)(176.9 \mathrm{~cm})$.

Interaction effect between levels and method of application of sulphur was found to be nonsignificant with the plant height of quality protein maize hybrid at all stages of the crop growth. Higher levels of sulphur dose increased plant height of maize plants, which may be attributed to multiple role of sulphur in protein and carbohydrate metabolism, activating many enzymes which influences photosynthesis and shoot length.

These results are in line with the findings of Dhananjay (1998), Bhagyalakshmi et al. (2010) and Choudhary et al., (2013). Adequate sulphur supply in split doses might have resulted in better utilization of sulphur to synthesize more carbohydrates to form more protoplasm, cell division, leaf expansion and improved vegetative growth of the plant which is in accordance with the results of Ahmad et al., (1998). 


\section{Leaf Area Index (LAI)}

The results on LAI of quality protein maize at different crop growth stages as influenced by sulphur levels and method of application are presented in table 3. LAI was significantly influenced by sulphur levels and method of application. Increasing sulphur levels from 10 to $40 \mathrm{~kg} \mathrm{ha}^{-1}$ progressively improved leaf area index of quality protein maize from 30, 60, 90 DAS and up to harvest stage.

Leaf area index of maize crop was significantly influenced by sulphur levels at 30 DAS. Among the four sulphur levels higher LAI was observed with $\mathrm{S}_{4}$ (1.61), followed by $S_{3}$ (1.41) and $S_{2}$ (1.21), while lowest LAI of 1.03 was recorded with $S_{1}$. LAI of crop was not influenced due to method of application of sulphur at early stages of crop growth. Similarly, at 60 DAS, significantly maximum LAI (3.76) was observed with 40 $\mathrm{kg} \mathrm{S} \mathrm{ha}{ }^{-1}$. Minimum LAI of 3.18 was noticed when maize crop was fertilized with $10 \mathrm{~kg}$ sulphur application. Split application of sulphur at basal and at knee heigh stage $\left(\mathrm{M}_{2}\right)$ resulted in maximum leaf area index (3.59) followed by conventional method of application (3.33) $\left(\mathrm{M}_{1}\right)$ and this difference were statistically significant. The data at 90 DAS on LAI revealed that, as the crop advanced to 90 days, the LAI increased progressively with sulphur levels. Among the four sulphur levels, significantly higher LAI of 4.53 was observed with $40 \mathrm{~kg} \mathrm{~S}^{-1}$, over that of obtained with $30 \mathrm{~kg} \mathrm{ha}^{-1}(4.23), 20 \mathrm{~kg}$ $\mathrm{S} \mathrm{ha}^{-1}$ (3.91), while the least leaf area index was shown when was maize fertilized with 10 $\mathrm{kg} \mathrm{S} \mathrm{ha}{ }^{-1}$ (3.68). In method of sulphur application, the LAI was found significantly superior in split application as 50\% basal and $50 \%$ at knee heigh stage (4.28) compared to $100 \%$ basal application (3.90).

At harvest, as the crop reached maturity and with senescence irrespective of the treatments, the LAI decreased compared to 30, 60 and 90 DAS. However, even at harvest, $40 \mathrm{~kg} \mathrm{~S} \mathrm{ha}^{-1}$ had resulted in higher LAI of 3.66 which was significantly. Superior over all other lower rates of sulphur application, split application of sulphur as basal and at knee heigh stage $\left(\mathrm{M}_{2}\right)$ recorded higher LAI of 3.54 while lower LAI (3.15) was seen with maize when sulphur was applied basally $\left(\mathrm{M}_{1}\right)$.

Interaction effect between levels and method of application of sulphur was non-significant with regard to LAI of quality protein maize hybrid at all growth stages. Leaf area index is an important plant index determining the capacity of plants in trapping solar energy for photosynthesis. Progressive increase in LAI was due to increased sulphur application, which increased nutrient uptake thereby enhancing rate of photosynthesis and leaf expansion. These results are similar to the findings of Khan et al., (2005) Daniela et al., (2008) and Tanveer et al., (2013). Application of the entire amount of sulphur in a single basal dose may not meet the increased demand for sulphur during crop growth, and results in a rapid decline in leaf area index due to increased senescence of the leaves. Hence split application of sulphur leads to better leaf area expansion, which helped in subsequent interception and efficient utilization of solar radiation. These findings were supported by Ahmad et al., 2005; Saeed et al., 2015.

\section{Dry matter production $\left(\mathrm{kg} \mathrm{ha}^{-1}\right)$}

Results regarding dry matter production revealed that it was significantly influenced by sulphur levels and method of application at all stages of crop growth i.e. from 30 DAS up to harvest which is presented in table 4. Perusal of data indicates that at 30 DAS, dry matter production was significantly influenced by sulphur levels. Among the four 
sulphur levels the dry matter production was significantly higher $\left(5215 \mathrm{~kg} \mathrm{ha}^{-1}\right)$ with $40 \mathrm{~kg}$ $\mathrm{S} \mathrm{ha}{ }^{-1}$, followed by $30 \mathrm{~kg} \mathrm{ha}^{-1}\left(4855 \mathrm{~kg} \mathrm{ha}^{-1}\right)$ and $20 \mathrm{~kg} \mathrm{~S} h a^{-1}$ (4365 kg ha $\left.{ }^{-1}\right)$. Lower dry matter production of $4026 \mathrm{~kg} \mathrm{ha}^{-1}$ was obtained by maize crop when applied with 10 $\mathrm{kg}$ sulphur application. Among the method of sulphur application, the dry matter production was found to be non-significant. Among the four sulphur levels, the data at 60 DAS indicates that $40 \mathrm{~kg} \mathrm{~S} \mathrm{ha}^{-1}$ had given significantly higher dry matter production $\left(8990 \mathrm{~kg} \mathrm{ha}^{-1}\right)$ followed by $30 \mathrm{~kg} \mathrm{~S} \mathrm{ha}^{-1}(8585$ $\left.\mathrm{kg} \mathrm{ha}^{-1}\right)$. Sulphur when fertilized with $10 \mathrm{~kg}$ $\mathrm{ha}^{-1}$ had produced the plants with the least dry matter production of $7709 \mathrm{~kg} \mathrm{ha}^{-1}$ at 60 days after sowing. Within the two method of application, split application $\left(\mathrm{M}_{2}\right)$ of sulphur as $50 \%$ as basal and $50 \%$ at knee heigh stage had resulted in more dry matter production $\left(8513 \mathrm{~kg} \mathrm{ha}^{-1}\right)$ compared to $100 \%$ basal application $\left(8202 \mathrm{~kg} \mathrm{ha}^{-1}\right)$ i.e. $\left(\mathrm{M}_{1}\right)$. As the crop advanced to 90 DAS, the dry matter production increased progressively with sulphur levels and method of application. The four levels of sulphur significantly influenced the dry matter production at $90 \mathrm{DAS}$, where maximum dry matter production of $12116 \mathrm{~kg}$ $\mathrm{ha}^{-1}$ was noticed with $40 \mathrm{~kg} \mathrm{~S}^{-1}$ which was significantly superior over the dry matter production obtained with $30 \mathrm{~kg} \mathrm{~S} \mathrm{ha}^{-1}$ (11640 $\left.\mathrm{kg} \mathrm{ha}^{-1}\right)$, followed by $20 \mathrm{~kg} \mathrm{ha}^{-1}\left(11021 \mathrm{~kg} \mathrm{ha}^{-}\right.$ $\left.{ }^{1}\right) .10 \mathrm{~kg} \mathrm{~S} \mathrm{ha}^{-1}$ had produced the least dry matter production of $10558 \mathrm{~kg} \mathrm{ha}^{-1}$ compared with other levels.

Application of sulphur in split dose both as basal and at knee heigh stage $\left(\mathrm{M}_{2}\right)$ had shown higher dry matter production of $11540 \mathrm{~kg} \mathrm{ha}^{-1}$ significantly superior to conventional method of sulphur application $\left(11127 \mathrm{~kg} \mathrm{ha}^{-1}\right)\left(\mathrm{M}_{1}\right)$.

Table.1 Initial and final population $\left(000 \mathrm{ha}^{-1}\right)$ of QPM as influenced by sulphur levels and method of application

\begin{tabular}{|c|c|c|c|c|c|c|}
\hline & \multicolumn{3}{|c|}{ Initial population } & \multicolumn{3}{|c|}{ Final population } \\
\hline $\begin{array}{l}\text { Sulphur levels } \\
\text { (S) }\end{array}$ & $\begin{array}{c}\text { Basal } \\
\left(\mathbf{M}_{1}\right)\end{array}$ & Split $\left(\mathbf{M}_{2}\right)$ & Mean & $\begin{array}{c}\text { Basal } \\
\left(\mathbf{M}_{1}\right)\end{array}$ & Split $\left(\mathbf{M}_{2}\right)$ & Mean \\
\hline $\mathrm{S}_{1}: 10 \mathrm{~kg} \mathrm{ha}^{-1}$ & 79.61 & 81.09 & 80.35 & 78.28 & 78.09 & 78.18 \\
\hline $\mathrm{S}_{2}: 20 \mathrm{~kg} \mathrm{ha}^{-1}$ & 81.20 & 81.44 & 81.32 & 78.20 & 78.78 & 78.49 \\
\hline $\mathrm{S}_{3}: 30 \mathrm{~kg} \mathrm{ha}^{-1}$ & 81.30 & 81.86 & 81.58 & 78.63 & 79.20 & 78.91 \\
\hline $\mathrm{S}_{4}: 40 \mathrm{~kg} \mathrm{ha}^{-1}$ & 81.33 & 82.53 & 81.93 & 77.66 & 80.86 & 79.26 \\
\hline Mean & 80.86 & 81.73 & & 78.19 & 79.23 & \\
\hline & SEm \pm & $\begin{array}{c}C D \\
(p=0.05)\end{array}$ & & SEm \pm & $\begin{array}{c}\text { CD } \\
(p=0.05)\end{array}$ & \\
\hline S & 0.83 & NS & & 1.05 & $\mathrm{NS}$ & \\
\hline M & 0.58 & NS & & 0.74 & NS & \\
\hline $\mathrm{S} \times \mathrm{M}$ & 1.17 & NS & & 1.48 & NS & \\
\hline
\end{tabular}


Table.2 Plant height $(\mathrm{cm})$ of QPM as influenced by sulphur levels and method of application

\begin{tabular}{|c|c|c|c|c|c|c|c|c|c|c|c|c|}
\hline & \multicolumn{3}{|c|}{ 30DAS } & \multicolumn{3}{|c|}{ 60DAS } & \multicolumn{3}{|c|}{ 90DAS } & \multicolumn{3}{|c|}{ At Harvest } \\
\hline Sulphur levels (S) & $\begin{array}{c}\text { Basal } \\
\left(M_{1}\right)\end{array}$ & $\begin{array}{l}\text { Split } \\
\left(\mathbf{M}_{2}\right)\end{array}$ & Mean & $\begin{array}{c}\text { Basal } \\
\left(M_{1}\right)\end{array}$ & $\begin{array}{l}\text { Split } \\
\left(\mathbf{M}_{2}\right)\end{array}$ & Mean & $\begin{array}{c}\text { Basal } \\
\left(\mathbf{M}_{1}\right)\end{array}$ & $\begin{array}{c}\text { Split } \\
\left(\mathbf{M}_{2}\right)\end{array}$ & Mean & $\begin{array}{c}\text { Basal } \\
\left(M_{1}\right)\end{array}$ & $\begin{array}{l}\text { Split } \\
\left(\mathbf{M}_{2}\right)\end{array}$ & Mean \\
\hline $\mathrm{S}_{1}: 10 \mathrm{~kg} \mathrm{ha}^{-1}$ & 39.2 & 41.4 & 40.3 & 145.2 & 148.4 & 146.8 & 161.8 & 165.0 & 163.4 & 164.5 & 168.4 & 166.4 \\
\hline $\mathrm{S}_{2}: 20 \mathrm{~kg} \mathrm{ha}^{-1}$ & 43.5 & 45.7 & 44.6 & 151.0 & 153.7 & 152.4 & 168.6 & 173.2 & 170.5 & 169.9 & 177.6 & 173.7 \\
\hline $\mathrm{S}_{3}: 30 \mathrm{~kg} \mathrm{ha}^{-1}$ & 47.2 & 49.9 & 48.5 & 158.7 & 164.2 & 161.5 & 174.5 & 182.2 & 178.3 & 179.8 & 185.2 & 182.5 \\
\hline $\mathrm{S}_{4}: 40 \mathrm{~kg} \mathrm{ha}^{-1}$ & 50.8 & 52.9 & 51.8 & 168.0 & 172.0 & 170.0 & 187.7 & 190.4 & 189.0 & 193.4 & 195.4 & 194.4 \\
\hline Mean & 45.2 & 47.4 & & 155.7 & 159.6 & & 173.1 & 177.7 & & 176.9 & 181.6 & \\
\hline & SEm \pm & $\begin{array}{c}C D \\
(p=0.05)\end{array}$ & & SEm \pm & $\begin{array}{c}C D \\
(p=0.05)\end{array}$ & & SEm \pm & $\begin{array}{c}C D \\
(p=0.05)\end{array}$ & & $\mathrm{SEm} \pm$ & $\begin{array}{c}\mathrm{CD} \\
(\mathrm{p}=0.05)\end{array}$ & \\
\hline $\mathrm{S}$ & 1.15 & 3.33 & & 1.73 & 4.90 & & 1.94 & 5.55 & & 2.08 & 6.03 & \\
\hline $\mathrm{M}$ & 0.81 & NS & & 1.22 & 3.46 & & 1.37 & 3.92 & & 1.47 & 4.26 & \\
\hline $\mathrm{S} \times \mathrm{M}$ & 1.71 & NS & & 2.45 & NS & & 2.74 & $\mathrm{NS}$ & & 2.94 & NS & \\
\hline
\end{tabular}

Table.3 Leaf area index (LAI) of QPM as influenced by sulphur levels and method of application

\begin{tabular}{|c|c|c|c|c|c|c|c|c|c|c|c|c|}
\hline & \multicolumn{3}{|c|}{ 30DAS } & \multicolumn{3}{|c|}{ 60DAS } & \multicolumn{3}{|c|}{ 90DAS } & \multicolumn{3}{|c|}{ At Harvest } \\
\hline Sulphur levels (S) & $\begin{array}{l}\text { Basal } \\
\left(\mathbf{M}_{1}\right)\end{array}$ & $\begin{array}{l}\text { Split } \\
\left(\mathbf{M}_{2}\right)\end{array}$ & Mean & $\begin{array}{l}\text { Basal } \\
\left(\mathbf{M}_{1}\right)\end{array}$ & $\begin{array}{l}\text { Split } \\
\left(\mathbf{M}_{2}\right)\end{array}$ & Mean & $\begin{array}{l}\text { Basal } \\
\left(\mathbf{M}_{1}\right)\end{array}$ & $\begin{array}{l}\text { Split } \\
\left(\mathbf{M}_{2}\right)\end{array}$ & Mean & $\begin{array}{l}\text { Basal } \\
\left(\mathbf{M}_{1}\right)\end{array}$ & $\begin{array}{l}\text { Split } \\
\left(\mathbf{M}_{2}\right)\end{array}$ & Mean \\
\hline $\mathrm{S}_{1}: 10 \mathrm{~kg} \mathrm{ha}^{-1}$ & 1.00 & 1.06 & 1.03 & 3.10 & 3.26 & 3.18 & 3.53 & 3.83 & 3.68 & 2.93 & 3.20 & 3.06 \\
\hline$S_{2}: 20 \mathrm{~kg} \mathrm{ha}^{-1}$ & 1.23 & 1.20 & 1.21 & 3.13 & 3.53 & 3.33 & 3.73 & 4.10 & 3.91 & 3.10 & 3.33 & 3.21 \\
\hline $\mathrm{S}_{3}: 30 \mathrm{~kg} \mathrm{ha}^{-1}$ & 1.30 & 1.53 & 1.41 & 3.40 & 3.73 & 3.56 & 4.00 & 4.46 & 4.23 & 3.20 & 3.70 & 3.45 \\
\hline $\mathrm{S}_{4}: 40 \mathrm{~kg} \mathrm{ha}^{-1}$ & 1.50 & 1.73 & 1.61 & 3.70 & 3.83 & 3.76 & 4.33 & 4.73 & 4.53 & 3.40 & 3.93 & 3.66 \\
\hline Mean & 1.25 & 1.38 & & 3.33 & 3.59 & & 3.90 & 4.28 & & 3.15 & 3.54 & \\
\hline & SEm \pm & $\begin{array}{c}C D \\
(p=0.05)\end{array}$ & & SEm \pm & $\begin{array}{c}C D \\
(p=0.05)\end{array}$ & & SEm \pm & $\begin{array}{c}\mathrm{CD} \\
(\mathrm{p}=0.05)\end{array}$ & & SEm \pm & $\begin{array}{c}C D \\
(p=0.05)\end{array}$ & \\
\hline $\mathrm{S}$ & 0.06 & 0.18 & & 0.07 & 0.20 & & 0.10 & 0.29 & & 0.07 & 0.20 & \\
\hline $\mathrm{M}$ & 0.04 & NS & & 0.04 & 0.11 & & 0.07 & 0.20 & & 0.05 & 0.14 & \\
\hline $\mathrm{S} \times \mathrm{M}$ & 0.09 & NS & & 0.09 & NS & & 0.15 & $\mathrm{NS}$ & & 0.10 & $\mathrm{NS}$ & \\
\hline
\end{tabular}


Table.4 Dry matter production (kg ha-1) of QPM as influenced by sulphur levels and method of application

\begin{tabular}{|c|c|c|c|c|c|c|c|c|c|c|c|c|}
\hline \multirow[b]{2}{*}{ Sulphur levels (S) } & \multicolumn{3}{|c|}{ 30DAS } & \multicolumn{3}{|c|}{ 60DAS } & \multicolumn{3}{|c|}{ 90DAS } & \multicolumn{3}{|c|}{ At Harvest } \\
\hline & $\begin{array}{l}\text { Basal } \\
\left(\mathbf{M}_{1}\right)\end{array}$ & $\begin{array}{l}\text { Split } \\
\left(\mathbf{M}_{2}\right)\end{array}$ & Mean & $\begin{array}{l}\text { Basal } \\
\left(\mathbf{M}_{1}\right)\end{array}$ & $\begin{array}{l}\text { Split } \\
\left(\mathbf{M}_{2}\right)\end{array}$ & Mean & $\begin{array}{l}\text { Basal } \\
\left(\mathbf{M}_{1}\right)\end{array}$ & $\begin{array}{l}\text { Split } \\
\left(\mathbf{M}_{2}\right)\end{array}$ & Mean & $\begin{array}{l}\text { Basal } \\
\left(\mathbf{M}_{1}\right)\end{array}$ & $\begin{array}{l}\text { Split } \\
\left(\mathbf{M}_{2}\right)\end{array}$ & Mean \\
\hline $\mathrm{S}_{1}: 10 \mathrm{~kg} \mathrm{ha}^{-1}$ & 3883 & 4168 & 4026 & 7563 & 7856 & 7709 & 10378 & 10739 & 10558 & 10512 & 10839 & 10675 \\
\hline $\mathrm{S}_{2}: 20 \mathrm{~kg} \mathrm{ha}^{-1}$ & 4225 & 4506 & 4365 & 7978 & 8314 & 8146 & 10880 & 11162 & 11021 & 10987 & 11269 & 11128 \\
\hline $\mathrm{S}_{3}: 30 \mathrm{~kg} \mathrm{ha}^{-1}$ & 4791 & 4919 & 4855 & 8395 & 8775 & 8585 & 11416 & 11864 & 11640 & 11520 & 11981 & 11750 \\
\hline $\mathrm{S}_{4}: 40 \mathrm{~kg} \mathrm{ha}^{-1}$ & 5167 & 5264 & 5215 & 8872 & 9108 & 8990 & 11836 & 12396 & 12116 & 11937 & 12500 & 12218 \\
\hline Mean & 4516 & 4714 & & 8202 & 8513 & & 11127 & 11540 & & 11239 & 11647 & \\
\hline & SEm \pm & $\begin{array}{l}\mathrm{CD} \\
(\mathrm{p}=0.05)\end{array}$ & & SEm \pm & $\begin{array}{l}\mathrm{CD} \\
(\mathrm{p}=0.05)\end{array}$ & & SEm \pm & $\begin{array}{l}\text { CD } \\
(p=0.05)\end{array}$ & & SEm \pm & $\begin{array}{l}\mathrm{CD} \\
(\mathrm{p}=0.05)\end{array}$ & \\
\hline $\mathrm{S}$ & 106 & 309 & & 135 & 391 & & 150 & 436 & & 153 & 448 & \\
\hline $\mathrm{M}$ & 75 & NS & & 96 & 278 & & 106 & 308 & & 108 & 316 & \\
\hline $\mathrm{S} \times \mathrm{M}$ & 151 & NS & & 192 & NS & & 212 & NS & & 216 & NS & \\
\hline
\end{tabular}


Table.5 Days to 50\% flowering of QPM as influenced by sulphur levels and method of application

\begin{tabular}{|c|c|c|c|c|c|c|}
\hline & \multicolumn{3}{|c|}{ Days to $50 \%$ tasseling } & \multicolumn{3}{|c|}{ Days to 50\% silking } \\
\hline $\begin{array}{l}\text { Sulphur levels } \\
\text { (S) }\end{array}$ & $\begin{array}{c}\text { Basal } \\
\left(\mathbf{M}_{1}\right)\end{array}$ & Split $\left(\mathbf{M}_{2}\right)$ & Mean & $\begin{array}{c}\text { Basal } \\
\left(\mathrm{M}_{1}\right)\end{array}$ & Split $\left(\mathbf{M}_{2}\right)$ & Mean \\
\hline $\mathrm{S}_{1}: 10 \mathrm{~kg} \mathrm{ha}^{-1}$ & 51.0 & 51.6 & 51.3 & 54.0 & 54.6 & 54.3 \\
\hline $\mathrm{S}_{2}: 20 \mathrm{~kg} \mathrm{ha}^{-1}$ & 52.6 & 53.0 & 52.8 & 55.3 & 56.3 & 55.8 \\
\hline $\mathrm{S}_{3}: 30 \mathrm{~kg} \mathrm{ha}^{-1}$ & 54.0 & 54.4 & 54.2 & 57.0 & 57.6 & 57.3 \\
\hline $\mathrm{S}_{4}: 40 \mathrm{~kg} \mathrm{ha}^{-1}$ & 54.6 & 57.0 & 55.8 & 58.3 & 60.0 & 59.1 \\
\hline Mean & 53.0 & 54.0 & & 56.1 & 57.1 & \\
\hline & SEm \pm & $\begin{array}{c}C D \\
(p=0.05)\end{array}$ & & SEm \pm & $\begin{array}{c}C D \\
(p=0.05)\end{array}$ & \\
\hline $\mathrm{S}$ & 0.46 & 1.35 & & 0.49 & 1.44 & \\
\hline M & 0.32 & NS & & 0.35 & NS & \\
\hline $\mathrm{S} \times \mathrm{M}$ & 0.65 & NS & & 0.70 & NS & \\
\hline
\end{tabular}

As the crop reached the harvest stage there was only marginal increase of dry matter production compared to 90 DAS. Sulphur applied at $40 \mathrm{~kg} \mathrm{ha}^{-1}$ had shown higher dry matter production of $12218 \mathrm{~kg} \mathrm{ha}^{-1}$, followed by $30 \mathrm{~kg} \mathrm{ha}^{-1}\left(11750 \mathrm{~kg} \mathrm{ha}^{-1}\right)$. Least dry matter production of $10675 \mathrm{~kg} \mathrm{ha}^{-1}$ was noticed with $10 \mathrm{~kg} \mathrm{~S} \mathrm{ha}^{-1}$. Split application of sulphur as basal and at knee heigh stage $\left(\mathrm{M}_{2}\right)$ had reported maximum dry matter production at harvest stage $\left(11647 \mathrm{~kg} \mathrm{ha}^{-1}\right)$ compared to basal application of sulphur applied (11239 $\left.\mathrm{kg} \mathrm{ha}^{-1}\right)\left(\mathrm{M}_{1}\right)$.

Interaction effect between levels and method of application of sulphur was found nonsignificant on the dry matter production of quality protein maize hybrid. The larger photosynthetic area and prolonged photosynthesis due to leaf area index and number of leaves per plant lead to higher dry matter production because of higher and balanced supply of sulphur fertilizers. Kochar et al., (1990), Srinivasrao et al., (2010) and Nanthakumar et al., (2014) also noticed higher dry matter production in maize due to positive effects of sulphur. Split application of sulphur at vegetative stage resulted in higher biomass accumulation due to production of more photosynthates. These results also confirm the findings of Havlin et al., (2004) and Wang et al., (2014).

\section{Days to $50 \%$ flowering}

Results (Table 5) revealed that days to $50 \%$ flowering was significantly influenced by sulphur levels and while method of application had not shown any significant effect. Among the four levels of sulphur, days to $50 \%$ tasseling was delayed when maize was fertilized with highest dose of sulphur at $40 \mathrm{~kg} \mathrm{ha}^{-1}$ (55.8 days), and 54.2 days with $30 \mathrm{~kg} \mathrm{~S} \mathrm{ha}^{-1}$ and 52.8 days in maize crop fertilized with $20 \mathrm{~kg} \mathrm{~S} \mathrm{ha}^{-1}$. It was observed that tasseling occurred earlier 51.3 
days when maize was fertilized with $10 \mathrm{~kg} \mathrm{~S}$ $\mathrm{ha}^{-1}$. Days to $50 \%$ Silking was delayed (59.1 days) when maize was applied with highest dose of sulphur of $40 \mathrm{~kg} \mathrm{ha}^{-1}$, followed by 57.3 days with $30 \mathrm{~kg} \mathrm{~S} \mathrm{ha}{ }^{-1}$. It was observed that silking was attained earlier 54.3 days when maize was applied with $10 \mathrm{~kg} \mathrm{~S} \mathrm{ha}^{-1}$.

The days to $50 \%$ tasseling and silking were not influenced by method of sulphur application i.e. $100 \%$ basal application $\left(\mathrm{M}_{1}\right)$ and split application $\left(\mathrm{M}_{2}\right)(50 \%$ as basal+ $50 \%$ at knee heigh stage). Combined effect of sulphur levels and method of sulphur application was non- significant with regard to days to $50 \%$ flowering. The abundant supply of fertilizers to the crop will promote vegetative growth for long duration, there by delaying flowering compared to the treatments where quality protein maize was supplied with less or without fertilizers, which attained flowering earlier. These results are in accordance with the findings of Kumar, 2008, Ali et al., (2013) and Rani et al., (2013).

In conclusion, Based on the results obtained in this investigation it can be concluded that, out of four levels of sulphur and two methods of sulphur application tested, in levels $40 \mathrm{~kg}$ sulphur $\mathrm{ha}^{-1}$ and split application in basal and knee heigh stage was ideal for increasing the growth and growth parameters of the quality protein maize crop. So our results suggested that using the different levels of sulphur along with split application provide sulphur to the crop during the entire period of its growth and development.

\section{References}

Ahmad, A., Khan, I., Anjum, N.A., Diva, I., Abdin, M.Z. and Iqbal, M. 2005. Effect of timing of sulphur fertilizer application on growth and yield of rapeseed. J. Plant Nutri., 28: 10491059.
Ahmad, A.G., Abrol, Y.P. and Abdin, M.Z. 1998. Effect of split application of sulphur and nitrogen on growth and yield attributes of Brassica genotype differing in time of flowering. Canadian J. Plant Sci., 181: 193-199.

Ali, A., Iqbal, Z., Hassan, S.W. and Muhammadyasin. 2013. Effect of nitrogen and sulphur on phenology, growth and yield parameters of maize crop. Sci. Int., 25(2): 363-366.

Bhagyalakshmi, T., Prakash, H.C. and Sudhir, K. 2010. Effect of different sources and levels of sulphur on the performance of rice and maize and properties of soils. Mysore J. Agri. Sci., 44(1): 79-88.

Choudhary, R., Singh, D., Singh, P., Dadarwal, R.S. and Chaudhari, R. 2013. Impact of nitrogen and sulphur fertilization on yield, quality and uptake of nutrient by maize in southern Rajasthan. Annals of Plant and Soil Res., 15 (2): 118-121.

Daniela, O., Pietkiewicz, S., Ciesinski, M., Kucinska, K. and Gowsdozki, G. 2008. Biomass accumulation and absorption of photosynthetic active radiation by rapeseed depending on sulphur fertilization. World J. Agri. Sci., 4: 133136.

Dhananjaya, B.C. 1998. Chemistry of sulphur and response of maize (Zea mays L.) to sulphur application in an alfisols of north Karnataka. M. Sc. Thesis. University of Agricultural Science, Dharwad, India.

Havlin, J.L., Beaton, J.D., Tisdale, S.L. and Nelson, W.L. 2004. Soil fertility and fertilizers: An introduction to nutrient management, $7^{\text {th }}$ edition. New Jersey, Pearson Prentice Hall. 528.

Khan, N.A. and Mobin, M. 2005. The influence of gibberellic acid and sulphur fertilization rate on growth and S-use efficiency of mustard (Brassica juncea). J. Plant and Soil, 270: 269-274. 
Kochar, R.K., Arora, B.R. and Nayyar, V.K. 1990. Effect of sulphur and zinc application on maize crop. Journal of Indian Soc. Soil Sci., 38: 339-341.

Kumar, A. 2008. Productivity, economics and nitrogen use efficiency of speciality corn (Zea mays) as influenced by planting density and nitrogen fertilization. Indian J. Agronomy, 53 (4): 306:309.

Lakkineni, K.C. and Abrol, Y.P. 1994. Sulphur requirements of crop plants: Physiological Analysis. Fertilizer News, 39 (3): 11-18.

Muhammad, T. 1994. Impact of water and nutrient management on growth, yield and quality of maize (Zea mays L.) Ph.D Thesis, Department of Agronomy, University of Agriculture, Faisalabad.

Nanthakumar, S., Panneerselvam, P. and krishnakumar. S. 2014. Effect of phosphorous and sulphur on growth, yield and quality parameters of hybrid maize. Int. J. Adv. Life Sci., 7(1): 85-92.

Patil, M.N., Deshmukh, P.W., Nikesar, R.J. and Naphade, K.T. 1998. Response of groundnut to sulphur and farmyard manure on Lithic Ustorthent. Panjabrao Deshmukh Krishi Vidyapeet Res. J., 22(1): 13-15.

Rani, P.L., Sreenivas, G., Reddy, D.R., Rao, V.P., Surekha, K. and Shiva Shankar, A. 2013. Influence of dates of sowing and $\mathrm{N}$ levels on growth and yield of kharif maize under irrigated conditions in south telangana agro climatic zone of Andhra pradesh, India. Int. J. Bio Resources and Stress Management, 4: 34-42.

Saeed, B., Khan, A.Z., Khalil, S.K., Rahman, H., Ullah, F., Gul, H. and Akbar, H. 2013. Response of soil and foliar applied nitrogen and sulphur towards yield and yield attributes of wheat cultivars. Pak. J. Botany, 45(2): 435442.

Srinivasrao, Ch., Masood, Ali, Venkateshwaralu, S., Rupa, T.R., Singh, K.K., Sumanta Kundu, S. and Prasad, J.V.N.S. 2010. Direct and residual effects of integrated sulphur fertilization in maize (Zea mays)-chickpea (Cicer arietinum) cropping system on typic ustochrept. Indian J. Agronomy, 55(4): 259-263.

Tandon, H.L.S. 1991. Sulphur fertilizer for Indian agriculture. A guide book, fertilizer Development and Consultation Organization, New Delhi, India. 1-4.

Tanveer, M., Ehsanullah, Anjum, A.S., Bajwa, A.A. and Zahid, H. 2013. Improving maize growth and development in relation to soil applied elemental sulfur. Asian J. Agri. Biol., 1(4): 200-207.

Vasal, S.K. 1999. Quality protein maize story. Improving human nutrition through agriculture. Workshop by IRRI.

\section{How to cite this article:}

Navatha, N., K.P. Vani, P. Surendra Babu and Srinivas, A. 2017. Response of Growth of Quality Protein Maize (Qpm) as Influenced by Sulphur Levels and Method of Application. Int.J.Curr.Microbiol.App.Sci. 6(2): 1113-1122. doi: http://dx.doi.org/10.20546/ijcmas.2017.602.125 